motor development is clearly recognised in association with PNP deficiency, often being the presenting feature. ${ }^{2}$ The characteristics of the motor disorder have not been clearly defined, however, with previous papers referring to spastic quadriplegia or spastic diplegia. ${ }^{2} 3$

Two siblings described as having familial dysequilibrium/diplegia with $T$ lymphocyte deficiency ${ }^{4}$ have now retrospectively been found to have PNP deficiency, using cultured fibroblasts, at this hospital. Both parents had heterozygote values for PNP. These children were thought to be similar to those described by Hagberg et al as having familial ataxic diplegia with deficient cellular immunity. ${ }^{5}$ The four children described in these two papers, plus our own case, point to a fairly characteristic and identifiable clinical picture. This would seem to consist of a disequilibrium-that is, pronounced difficulty in maintaining posture and upright position giving rise to an early hypotonia, very unsteady and delayed sitting, and great difficulty in walking independently. In contrast there is either no, or only a mild, intention tremor or clumsiness. There is evidence of a spastic diplegia on clinical examination with brisk reflexes, upgoing plantars, and sometimes ankle clonus and restriction of passive dorsiflexion of the ankles. When walking this is masked by trunkal ataxia, however, particularly as the child gets older. The neurological picture appears to be non-progressive, may relate to the degree of guanosine triphosphate depletion and is non-infective in aetiology. ${ }^{2}$ Intelligence may be normal as in this case.

The haematological and immunological consequences of PNP deficiency relate to the depressed $T$ cell numbers and function, leading to repeated infections with viral illnesses often being the cause of death. These children should not receive live vaccinations. Lymphomas, often of a B cell origin, are also a complication of other immunodeficiency states, for example, AIDS, and have been described in PNP deficiency. ${ }^{3}$

Haematological findings in PNP deficiency are pure red cell aplasia, megaloblastic anaemia, autoimmune haemolytic anaemia, ${ }^{26}$ and maturation arrest at the myelocyte/metamyelocyte stage in bone marrow aspirates. ${ }^{3}$ Intracytoplas- mic neutrophil inclusions (figure) have not been previously described; they persisted after resolution of sepsis and in addition, identical inclusions were seen in the paternal blood film. Similar inclusions are well recognised during treatment with drugs that interfere with DNA synthesis such as azathioprine, chlorambucil, and appear to be fragments of DNA. DNA synthesis is impaired in PNP deficiency suggesting a similar aetiology.

Autoimmune disease is another complication of immune deficiency including PNP deficiency. ${ }^{2}$ Suspecting the neutropenia to be immune mediated, we treated our patient with 2 $\mathrm{g} / \mathrm{kg}$ intravenous immunoglobulin over two days. There followed a dramatic rise in the neutrophil count $\left(0 \cdot 4-2 \cdot 8 \times 10^{9} / 1\right)$. The patient had been persistently neutropenic for two months before this.

In conclusion, recognition of PNP deficiency before onset of severe infection or malignancy is important so that bone marrow transplantation from a suitable donor can be considered while the patient is well. Successful engraftment has already been documented in this condition. ${ }^{36}$ In addition, antenatal diagnosis is now possible for measuring PNP in chorionic villus samples. We consider familial dysequilibrium/diplegia with $\mathrm{T}$ lymphocyte deficiency and familial ataxic diplegia with deficient cellular immunity should no longer be considered separate disease entities, but reclassified as cases of PNP deficiency.

We thank Mr R Webber for his photographic and technical assistance.

1 Giblett ER, Ammann AJ, Wara DW, Sandman R, Diamond LK. Nucleoside phosphorylase deficiency in a child with severely defective $T$-cell immunity and normal B-cel immunity. Lancet 1975; i:1010-3.

2 Simmonds HA, Fairbanks LD, Morris GS, et al. Central nervous dysfuction and erythrocyte guanosine triphosphate depletion in purine nucleoside phosphorylase deficiency. Arch Dis Child 1987;62:385-91.

3 Watson AR, Evans DK, Marsden HB, Miller V, Rogers PA Purine nucleoside phosphorylase deficiency associated with a fatal lymphoproliferative disorder. Arch Dis Child 1981, 56:563-5.

4 Graham-Pole J, Gibson AAM, Stephenson JBP. Familial dysequilibrium-diplegia with $\mathrm{T}$ lymphocyte deficiency. Arch Dis Child 1975;50:927-32.

5 Hagberg B, Hansson O, Liden S, Nilsson K. Familial ataxic diplegia with deficient cellular immunity. Acta Paediatr diplegia with deficient

6 Hong $R$. Diseases due to immunologic deficiency. In Behrman RE, Vaughan VC, eds. Nelson textbook of pediatrics. Philadelphia: W B Saunders, 1987:461-7.
Catholic University of Louvain, Cliniques Universitaires Saint-Luc, 1301, B-1200 Brussels, Belgium, Department of Paediatrics Janclaire J Manclaire

Department of Virology Ch Cornu

Correspondence to: Dr Sokal.

Accepted 2 April 1991

(Arch Dis Child 1991;66:983-5)

\title{
Fulminant hepatitis B in an infant born to a hepatitis Be antibody positive, DNA negative carrier
}

\author{
J Vanclaire, Ch Cornu, E M Sokal
}

Abstract

A boy was born to a mother who was a chronic hepatitis B virus (HBV) carrier. She was hepatitis $\mathrm{Be}(\mathrm{HBe})$ antibody positive and $\mathrm{HBe}$ antigen and HBV-DNA negative. The boy had not received hepatitis $B$ vaccine and died from fulminant hepatitis at 3 months of age. This case demonstrates the need to vaccinate babies of $\mathrm{HBe}$ antibody positive, $\mathrm{HBe}$ antigen negative carriers. 
Perinatal transmission of hepatitis $B$ virus (HBV) is well documented in babies born to hepatitis $\mathrm{Be}(\mathrm{HBe})$ antigen positive mothers. ${ }^{1}$ Risk of contamination as well as natural history when the mother is $\mathrm{HBe}$ antigen negative is underestimated, however, and these babies are not always given $\mathrm{HBV}$ vaccination. We report the case of a child who died from fulminant hepatitis $\mathrm{B}$ and who was born to a $\mathrm{HBe}$ antigen and DNA negative mother.

\section{Case report}

A boy was born at full term to a healthy HBV carrier. She was hepatitis B surface (HBs) antigen positive, $\mathrm{HBe}$ antigen negative, hepatitis $\mathrm{B}$ core $(\mathrm{HBc})$ IgG antibody positive, $\mathrm{HBe}$ antibody positive, and HBV-DNA negative. The boy was not vaccinated and did not receive immune prophylaxis at birth. He had no contact with any other known HBV carrier.

At 3 months old he was admitted to hospital because of vomiting, failure to thrive, jaundice, and hepatomegaly. He was irritable. Liver and spleen were not palpable and he had mild ascites. Biochemical investigations are shown in the table. He was HBc IgM antibody positive, $\mathrm{HBs}$ antigen positive, $\mathrm{HBe}$ antigen negative, and $\mathrm{HBe}$ antibody positive. Serology for hepatitis A virus, cytomegalovirus, EpsteinBarr virus, HIV, and toxoplasmosis were negative. He had passive immunisation for rubella and herpes simplex virus. His urine was sterile. He had received no sucrose and no drugs, and urinary reducing substances were negative. Erythrocyte uridyldiphosphate galactosyl transferase activity and serum tyrosine concentrations were normal. Liver ultrasonography showed appreciable parenchymal atrophy, normal biliary tract, and ascites. He was registered on the urgent list for liver transplantation and was admitted to the intensive care unit. Within 24 hours his condition deteriorated, encephalopathy progressed, and he died from liver insufficiency.

His mother's HBV serological markers were identical to those at her prenatal investigations and there was no HBV-DNA detected in serum by liquid phase molecular hybridisation (Abbott).

\section{Discussion}

It is commonly thought that the risk of $\mathrm{HBV}$ transmission is absent or low when the hepatitis

Results of biochemical investigations (normal results are shown in parentheses)

\begin{tabular}{|c|c|}
\hline $\begin{array}{l}\text { Total bilirubin } \\
\text { Direct bilirubin } \\
\text { Aspartate aminotransferase } \\
\text { Alanine aminotransferase } \\
\gamma \text {-glutamyltransferase } \\
\text { Total serum protein } \\
\text { Albumin } \\
\text { Prothrombin time } \\
\text { Glucose } \\
\text { Ammonia } \\
\text { Haemoglobin } \\
\text { White cell count }\end{array}$ & $\begin{array}{l}246 \cdot 2 \mu \mathrm{mol} / /(<17 \cdot 1) \\
85 \cdot 5 \mu \mathrm{mol} / \mathrm{l}(<3 \cdot 4) \\
128 \mathrm{IU} / \mathrm{l}(<25) \\
1223 \mathrm{IU} / /(<32) \\
38 \mathrm{IU} / \mathrm{l}(<45) \\
43 \mathrm{~g} / 1 \\
32 \mathrm{~g} / \mathrm{l} \\
>20 \mathrm{~seconds} \\
6 \cdot 9 \mathrm{mmol} / \mathrm{l} \\
91 \cdot 6 \mu \mathrm{mol} / /(<58 \cdot 7) \\
88 \mathrm{~g} / \mathrm{I} \\
3 \cdot 12 \times 10^{9} / 1 \\
\text { (neutrophils } 27 \%, \\
\text { lymphocytes } 51 \%) \\
421 \times 10^{9} / 1\end{array}$ \\
\hline
\end{tabular}

B carrier mother has developed anti-HBe antibodies. ${ }^{2}$ Because of this, babies born from these mothers may not be vaccinated at birth against hepatitis $B$ in developed countries. The risk of perinatal transmission is related to $\mathrm{HBs}$ antigen titre, $\mathrm{HBe}$ antigen positivity, and $\mathrm{HBV}$ specific DNA or DNA polymerase activity in maternal serum. ${ }^{2}$ However, case reports have shown that anti-HBe antibodies do not protect fully against $\mathrm{HBV}$ transmission, and 10 to $20 \%$ of babies born to $\mathrm{HBs}$ antigen positive, $\mathrm{HBe}$ antibody positive mothers may be infected. ${ }^{34}$ In one series half of these developed acute or even fatal hepatitis B. ${ }^{4}$ It is not known if maternal serum contained HBV-DNA in these cases. The present report demonstrates that even when no HBV-DNA is detected by hybridisation in serum of $\mathrm{HBs}$ antigen positive mothers, babies are at risk of developing postnatal hepatitis B. Mild viral replication can be present despite negativity of serum $\mathrm{HBe}$ antigen and HBV-DNA, ${ }^{5}$ and it is likely that the baby was contaminated at birth by maternal serum containing traces of HBV-DNA that was not detectable by DNA hybridisation. The child had had no contact with any other HBV carrier.

It is not known why when the mother is $\mathrm{HBe}$ antigen negative and HBs antigen positive the risk is greater of developing a severe or even fulminant hepatitis than in babies born from $\mathrm{HBe}$ antigen positive mothers. ${ }^{34}$ The host immunological response to infection is responsible for the hepatocellular lysis instead of the virus itself. Infants from $\mathrm{HBe}$ antigen negative mothers may be exposed to low doses of $\mathrm{HBV}$ particles and may develop an overwhelming response to infection causing massive immune medicated damage. On the other hand infants from $\mathrm{HBe}$ antigen positive mothers receive a lot of HBV. The capacity of their immune system to fight the infection might be exceeded and they do tend to become chronic asymptomatic carriers. ${ }^{34}$ It has also been suggested that HBV mutation may modify the course of chronic hepatitis and might prevent formation of normal $\mathrm{HBe}$ antigen. ${ }^{6}$ If this was the case in our patient we would have expected to find HBVDNA in maternal serum.

No other cause of liver disease was found in our patient. Although liver transplantation has not been performed in this particular situation in infants, the procedure can be successful in small children and the boy was therefore registered on the waiting list. ${ }^{7} \mathrm{He}$ unfortunately died before any donor could be found.

Our case report shows that $\mathrm{HBe}$ antibodies do not protect against perinatal $\mathrm{HBV}$ mother to child transmission, and that babies from $\mathrm{HBe}$ antibody positive, HBV-DNA negative carrier mothers are at risk of developing fulminant heptitis B. They should therefore also be included in vaccination programmes against hepitis $\mathrm{B}$.

\footnotetext{
Balistreri W. Viral hepatis. Pediatr Clin North Am 1988;35: 637-69.

2 Lee SD, Lo KJ, Wu JC. Prevention of maternal-infant hepatitis B virus transmission: the role of serum hepatitis B virus DNA. Hepatology 1988;6:369-73.

3 Tong M, Sinatra F, Thomas D, Nair P, Merrit R, Wang D.
} 
Need for immunoprophylaxis in infants born to HBs antigen positive carrier mothers who are $\mathrm{HBe}$ antigen negative. f Pediatr 1984;105:945-7.

4 Chang MH, Lee CY, Chen DS, Hsu HC, Lai MY. Fulminant hepatitis in children in Taiwan: the important role of hepatitis in children in Tawan: the importar

5 Kaneko S, Miller R, Feinstone S, et al. Detection of serum hepatis B virus DNA in patients with chronic hepatitis using the polymerase chain reaction assay. Proc Natl Acad Sci USA 1989;86:312-6.

6 Carman W, Hadziyannis S, Mac Garvey M. Mutation preventing formation of hepatitis $B$ e antigen in patients with venting formation of hepatitis B e antigen in patients with

7 Sokal EM, Veyckemans F, de Ville de Goyet J, et al. Liver transplantation in children less than one year of age. f Pediatr 1990;117:205-10.

\title{
Long term survival after heart transplantation for doxorubicin induced cardiomyopathy
}

\author{
Maurizio Aricò, Elisa Pedroni, Luigi Nespoli, Mario Viganò, Fulvio Porta, G Roberto Burgio
}

\begin{abstract}
A 10 year old child developed severe cardiomyopathy after combined, multicycle chemotherapy for Ewing's sarcoma and was treated by heart transplantation with good results. Long term azathioprine and cyclosporin caused only mild impairment of immune function and there were no recurrent infections, local recurrences of the tumour, or distant metastases.
\end{abstract}

Ewing's sarcoma is a malignant, round cell tumour of bone that occurs in later childhood and adolescence, which has a poor prognosis. ${ }^{12}$ Before the era of combination chemotherapy the five year survival rate was 5 to $10 \%{ }^{1}$ Aggressive chemotherapy has resulted in a mean three year disease free survival of almost $60 \% .^{3}$ This improvement is mainly the result of systemic chemotherapy, with better staging of patients or more efficient radiation regimens playing a small part.

Doxorubicin hydrochloride (Adriamycin) is an essential drug in combined, multicycle chemotherapy, ${ }^{12}$ although it is known (together with related drugs) to cause a cardiomyopathy that is usually dose dependent. ${ }^{4}$

We describe a child who, having developed a severe cardiomyopathy after combined, multicycle chemotherapy for Ewing's sarcoma, underwent heart transplantation with good results.

IRCCS Policlinico

S Matteo, I-27100

Pavia, Italy

University Department

of Paediatrics

Maurizio Aricò

Elisa Pedroni

Luigi Nespoli

Fulvio Porta

G Roberto Burgio

Heart Surgery Unit

Mario Viganò

Correspondence to:

Dr Arico.

Accepted 28 February 1991

(Arch Dis Child 1991;66:985-6)

\section{Case report}

An 8 year old boy with Ewing's sarcoma of the pelvis and proximal femur was treated with a four drug combination of chemotherapy (vincristine, cyclophosphamide, dactinomycin, and doxorubicin hydrochloride), plus local irradiation (protocol POG 8095), and conservative surgery. The total dose of doxorubicin that he received was $480 \mathrm{mg} / \mathrm{m}^{2}$. Despite regular monitoring of cardiac function by electrocardiography and echocardiograph scanning, severe cardiomyopathy developed 25 months after the diagnosis had been made. Cardiac function rapidly worsened and was soon so impaired that several episodes of congestive failure occurred during the subsequent weeks, leaving the child bedridden.

Twenty nine months after the diagnosis of Ewing's sarcoma and four months after the onset of cardiomyopathy, the child, by then 10 years old and with no evidence of residual tumour, underwent orthotopic transplantation of a heart from an 8 year old child who had been killed in a car accident. The postoperative course was uneventful. Signs of rejection were monitored by serial myocardial biopsies, and prevented by oral immunosuppressive drugs cyclosporin ( $5 \mathrm{mg} / \mathrm{kg} /$ day), methylprednisolone $(2 \mathrm{mg} / \mathrm{kg} /$ day), and azathioprine $(62.5 \mathrm{mg} /$ day). During the next few months the steroids were reduced to $5 \mathrm{mg}$ daily.

More than three years after transplantation the child is doing well: his heart function is normal, he attends school, and he is able to take part in normal physical activities. Repeated checks indicate that there is no local recurrence or distant metastases. His serum immunoglobulin concentrations were: IgG $14.5 \mathrm{~g} / 1$, IgA $4.7 \mathrm{~g} / \mathrm{l}$, and IgM $1.8 \mathrm{~g} / \mathrm{l}$. IgG subclass values were: $\operatorname{IgG}_{1} 8 \cdot 1 \mathrm{~g} / 1, \mathrm{IgG}_{2} 1 \cdot 8 \mathrm{~g} / \mathrm{l}, \mathrm{IgG}_{3} 1 \cdot 3 \mathrm{~g} / 1$ and $\mathrm{IgG}_{4} \mathbf{0 . 3} \mathrm{g} / \mathrm{l}$. Peripheral blood $\mathrm{T}$ lymphocyte subsets were: $\mathrm{CD} 3+83 \%, \mathrm{CD} 4+47 \%, \mathrm{CD} 8+$ $55 \%, \mathrm{CD} 11+83 \%, \mathrm{CD} 20+26 \%$, and CD16+ 6\%. Lymphocyte proliferative response to phytohaemagglutinin in vitro was $71 \cdot 7 \%$ of normal controls. Delayed type hypersensitivity skin testing evoked no response to any of the challenged antigens.

\section{Discussion}

Ewing's sarcoma is a malignant bone tumour that had a poor prognosis until combined chemotherapy including anthracyclines was introduced. The current five year disease free survival rate is about $60 \%$. Bacci et al recently reported a $7 \%$ risk of late relapse after that time, confirming other reports. ${ }^{3}$

We have reported a child who, 25 months after the diagnosis of Ewing's sarcoma, had achieved persistent local and systemic control but suffered from life threatening cardiomyopathy. The decision to attempt heart transplantation was difficult to take. On the one hand it was indicated because of the poor 